\title{
ASSESSMENT OF COOPERATION WITHIN CHOSEN SUPPLY SYSTEM IN THE CZECH CHEMICAL INDUSTRY
}

\author{
Vladimira Vlckova \\ Department of Economy and Management of Chemical and Food Industries, Faculty of Chemical Technology, \\ University of Pardubice, Studentska 95, 53210 Pardubice, Czech Republic \\ E-mail: vladimira.vlckova@upce.cz
}

\begin{abstract}
Cost effective creation of value through integration of logistic processes is considered as a significant source of competitive advantage of applied logistics. This transition to supply systems with a dynamic structure requires solutions to a number of problems; one of them is to setup the ways of cooperation between the entities inside supply chains. Application of different forms of cooperation depends on a lot of problems inter alia on branch characteristics and characteristics of the manufactured product. Therefore, this paper identifies and evaluates, on the basis of comparison of literature research outcomes and analysis of cooperation ways between partners within chosen supply system in the chemical industry, the ways, the conditions, and the advantages of this cooperation.
\end{abstract}

Keywords: supply chain, supply system, forms of cooperation, merger, acquisitions, chemical industry.

JEL Classification: L14; L22; L65.

\section{Introduction}

In the traditional functional arrangement of an organization, individual logistics activities were managed within separate corporate units (Ballou 2007). A significant problem of such separate logistics activities in individual functions is a discontinuous and inefficient material and information flow through the company, which results in a low productivity of the company, redundant activities, a prolonging chain of activities, higher costs, poor customer services, etc. (Waters 2003). Lack of collaboration in supply chain leads to inefficient production, redundant inventory stock, and inflated costs (Ling 2008). The possibility of elimination of these negative effects can be seen in the idea of integration of the logistics activities into a single logistics system of the company (Waters 2003). Traditional chains with discontinuous flows are then gradually replaced by chains with continuous flows. Companies are creating more and more complex and extensive supply systems within which they mostly cooperate on the basis of partnerships built on mutual cooperation, confidence, and willingness to share necessary data. It is a response of the companies to the turbulent changes in the current business environment, which are mainly caused by the advancing globalization of the economic environment on the one hand, and by the deepening differentiation of the markets on the other, finally resulting in fulfilment of requirements according to the wishes of individual customers (Gros, Grosova 2011). At the same time, the growth of of information technology and communication capabilities such as the Internet and e-commerce enhance the ability to integrate the chain (Stank et al. 2001; Murphy, Knemeyer 2015). Progressive methods are being developed and applied in logistics, economic entities are being distinctly interconnected in networks, logistics costs are being thoroughly monitored and optimized through integration of purchase, production and distribution, coordination and cooperation with the customers also with the suppliers are being deepened (Vlckova et al. 2012). And it was a substantial finding for companies that intangible flows are of the same importance as tangible flows (Rushton, Baker 2010) and that the value is generated in the entire structure of the supply system (Lostakova et al. 2009). The need for reforms in the company is also supported by the finding that the source of the value is not in the company units, but in the company processes (Christopher, Peck 2003; Christopher 2005).

The current logistics practice of successful companies points in direction to a system solution into the logistics concept and at the benefits of a longer time stabilization of supply chains, where it is easier to increase the logistics performance and quality. Creation of supply systems thus correlates with the current trend of interconnecting individual economic entities for the purpose of achieving 
synergistic effects, which may, in the environment of supply systems, include: increasing competitiveness, improving negotiation power, and maximization of the value generated by the system (Waters 2003). Within logistics, this means synchronization of a single logistics activity inside the company with logistics activities of other companies sharing the material flows. The need for management of tangible flows from the primary suppliers to the end customers was specified by Haskett as early as in 1964 (Ballou 2007). Top firms are developing extremely close relationships with selected clients and are placing significantly more emphasis on improved working arrangements with suppliers. It is generally believed that increased collaboration among supply chain participants leads to lower total cost and enhanced service performance. In the last decade, the concept of world-class logistics has expanded outside the boundaries of the firm to include customer and supplier integration (Stank et al. 2001).

This results in establishment of supply chains that are not described in the professional literature or understood uniformly. They are understood either as a sequence of activities (Waters 2003; Pernica 2004), or as a certain group of companies, or as their combination (Fiala 2009; Lambert et al. 1998; Ling 2008; Mentzer et al. 2001). However Gros and Grosova (2011) say that what is essential in accordance with the system theory is dividing activities from the owners of these activities. It means to differentiate the supply chain as a sequence of steps, activities, events, and processes from the supply system as a sequence, a network, a group of organizations. The supply chain is then defined as a sequence of activities within integrated and mutually interconnected logistics chains, including activities connected with implementation of reverse flows whose performance is necessary for fulfilment of the end customer's requirements within the required time period, quantity, quality, and to the required place. The supply system is understood as a specifically defined group of organizations and bonds between them, which participate in planning and performance of the sequence of activities defined in the supply chain (Gros, Grosova 2012). This approach is also applied in this paper.

However, it is a very complex task to create a logistics system. It consists in harmonization of various activities and different systems. In the competition of more and more complex supply systems, only the entities that not only apply modern management methods (Kostalova, Tetrevova 2014) but that are also able to change their struc- ture dynamically can succeed (Gros, Grosova 2011; Seifert 2003). The need for such changes is an extraordinarily hot issue also in the conditions of the Czech Republic, where a number of acquisitions and mergers take place. Such integration proceeds in single steps within periods of different lengths, within years or decades (Waters 2003). An example of a complex supply system in the Czech Republic can be found in group, which has taken a number of steps in the last more than 20 years, and these steps resulted in the situation where it controls not only a number of food companies, but also a number of companies dealing with chemistry, agriculture, etc. The research focused on monitoring of changes in the logistics management of chemical industry companies in the Czech Republic included a survey conducted in this group into very closely connected topics in the area of building a supply system and cooperation within this system. The study dealt with development of the structure of a significant supply system in the Czech Republic with respect to cooperation of companies in the chemical industry.

\section{Aims and methodology}

The paper aims to describe, assess, and analyze the selected supply system from the point of view of the Czech chemical industry with emphasis on cooperation of individual members. To meet this objective, the paper first defines, on the basis of the professional literature review, the basic features and structures of supply systems and describes the possibilities of cooperation of individual supply system members. The outcomes of the conducted survey mainly express the ways, conditions, and benefits of cooperation within the context of the dynamics of development of a particular supply system in the Czech chemical industry.

The survey was conducted in the form of analysis of the annual reports of the given group from 1993 to 2013, in-house magazines, and personal experience acquired during the research in a number of chemical companies, using the method of in-depth interviews with managers using the scenario of questioning. Directed questioning was then performed in 2014-5 within master's thesis with top managers and particularly with the manager responsible for logistics in one of the chemical companies of the given supply system (Vrbova 2015).

The knowledge of these conditions and benefits of cooperation then makes it possible to seek ways how to enhance synergistic effects resulting from it, i.e. in particular the competitiveness of 
companies in the Czech Republic and maximization of the value generated by the system.

\section{Supply system collaboration}

Ideally, collaboration begins with customers and extends back through the firm from finished goods distribution to manufacturing and raw material procurement, as well as to material and service suppliers. Thus, integration is needed both internally i.e. intraorganizationally and externally i.e. interorganizationally (Stank et al. 2011), and Harrison (2005) adds electronically. Firms with higer internal integration and collaboration demonstrated higher relative logistics performance, greater performance in terms of meeting customer needs, accommodating special customer requests and new product introductions. Internal integration is the starting point for broader integration and collaboration across the supply chain which reduces uncertainty of material flow (Harrison 2005). Electronically trading partners can collaborate in three ways: transactional, information sharing and collaborative planning. Transactional electronic collaboration is usually found in $\mathrm{B} 2 \mathrm{~B}$ e-commerce.

Supply chains are considered a key factor of corporate success (Estampe et al. 2013). The relations of collaboration across the supply chain, which particularly are the subject matter of the presented research, are based on creation a strategic partnership between two or more companies (partner).

These partnerships then include forms of cooperation of different closeness. They include mergers, acquisitions, strategic partnerships based on joint ownership, and strategic partnerships that are not based on joint ownership (Tetrevova, Vlckova 2012).

Merger is one of the possible forms of transformation of an artificial person. In accordance with the Civil Code, a merger refers to consolidation or fusion of at least two involved artificial persons. Upon a merger, at least one of them ceases to exist, and the rights and obligations are transferred to only one of the involved persons as the succession artificial person. Upon a merger, all the involved persons become extinct, and in their place a new artificial person comes into existence as the succession person to whom the rights and obligations of all the persons that cease to exist are transferred (Act No.89/2012 Sb. Civil Code 2012, $\S 178$ ). In the area of international business, it is possible to identify three basic types of mergers: horizontal, vertical, and conglomerate (Synek at al. 2007).
The horizontal merger refers to consolidation of companies (entities) from the same branch of business, with the same activity. Partners skills and expertise may overlap (Ling 2008). Its main objective is to achieve economies of scale and an increase on the global market share.

The vertical merger refers to consolidation of economic entities with the preceding or the consequent activity. Vertical partneship does not have overlap capability (Ling 2008). Fiala describes it as the situation where all the parties participating in the activities defined in the supply chain are in the ownership of one company (Fiala 2009). Waters classifies it as the highest possible form of integration, where one company buys another company within the supply system to cut costs and to improve the level of customer services (Waters 2007). It aims to strengthen the control over the suppliers or the customers. A sole owner contributes to the successful building of the system. A sole owner of the ownership group, affects the choice of suppliers and customers, sup-pliers belonging to the same ownership group become preferred (Branska et al. 2013). Companies cooperating this way can gain advantages, e.g. in the form of increased control over the performance and costs. That is why the vertical merger has belonged to the most popular ways of cooperation in the recent years.

The hybrid partnership integrates both horizontal and vertical partnership practices (Ling 2008).

The conglomerate merger refers to consolidation of companies from different areas of business, with a different economic activity across industries. It usually aims to diversify the corporate activities and to spread risks.

Takeover represents a takeover of a company on the basis of purchase and sale. It can have the character of an amicable or a hostile takeover (Synek et al. 2007). Its implementation is characterized by complete or partial loss of the economic independence of the company, but its legal independence remains unchanged.

Strategic partnerships based on joint ownership include joint ventures or groups-concern (Tetrevova 2012). A joint venture results from a direct investment made by two or more companies. They establish, on the basis of an agreement, an artificial person where they jointly create the capital and share its management. A joint venture can even originate without making any investments, but only on the basis of contractual relations (Synek et al. 2011). A group refers to the situation where one or more persons come under single 
management performed by another person or persons (Act No.90/2012 Sb. on business corporations $\S 79$ ). This single management ensures coordination and conceptual management of at least one of the significant components or activities within the group's business activities. It aims to advance the group's interests within its unified policy on a long-term basis.

Just mergers, acquisitions, or strategic partnerships based on joint ownership used to be considered by companies as the best forms of cooperation within coordination of activities in the supply system. The reasons included the fact that most companies were not willing to share information, the atmosphere of distrust among the companies, traditionally competitive relations to the other members of the system, different corporate cultures, management systems, etc. However, further surveys discovered that companies should focus more on the key processes and leave all the other activities to external suppliers (Christopher 2005), i.e. direct their attention also to cooperation which is not based on joint ownership.

Strategic partnerships that are not based on joint ownership are characterized both by formal (contractual) and informal cooperation, and by long-term relationships between the partners. This form of cooperation results in an increase in outsourcing with its advantages (e.g. the possibility of focusing on the key activities only, utilization of better expertise and more advanced technologies of the suppliers, decreasing the capital, stockpile, and costs), but also the disadvantages (e.g. the risk relating to interruption of deliveries, the possibility of violating a business secret, loss of control over the production procedure, the quality, the costs incurred in relation to the cooperation with the supplier). In the area of logistics services, 3PL, 4PL logistics providers and also providers of types 2PL, 5PL, LLP (Lead Logistics Provider) are being established to specialize in them (Vlckova, Patak 2012). The aim is to improve the material flow, to utilize the expertise and the technical background of the provider, to decrease the costs thanks to the economies of scale, to diminish the financial risks, to increase the level of specialization, etc. (Robeson et al. 1994).

The highest form of cooperation is virtual integration where "virtual enterprises" are established. Virtual enterprises use outsourcing to the maximum possible extent for all their activities, and they "just" coordinate activities of the other companies over the Internet in real-time to create maximum value (Ling 2008; Fiala 2009).
The level of collaboration in supply chain is closely associated with the product clock-speed. It can be fast, medium, or slow (Ling 2008). When new product introductions are frequent (short product life cycle) and product variety is high, the responsive supply chain option is more attractive as it reacts quickly to market demand. The responsive supply chain is also characterized by a low level of predictability of the demand and a high level of forecast failures. That is why its purpose is to respond quickly to any changes in the market demand by quick development new products, flexibility of the supply system, and flexible production. When product life cycle is long, product variety is low, demand is relatively stable, and demand volume is high, efficient supply chain is more appropriate. The aim is to coordinate material and service flows in the way to minimize the stockpile and to maximize the efficiency of manufacturers and service providers in the system (Ling 2008).

The above implies that the typical product for the chemical industry is a slow clock-speed product efficient supply chain and vertical integration.

New methods focused on strengthening partnerships between supply system members are being developed and applied in the interest of a continuous improvement of the intercompany material flow in the supply system (Lostakova et al. 2009). These methods, striving for effective material flow management with close attention to satisfying requirements and wishes of the end customers, are particularly based on the principle of common sharing of information and the possibility of replacing the stockpile by information through modern information technologies. It is possible to mention methods or approaches like Quick Response (QR), Efficient Customer Response (ECR), Continuous Replenishment Program (CRP), Vendor Managed Inventory (VMI) or, nowadays the most comprehensively oriented method Collaborative, Planning, Forecasting and Replenishment (CPFR) (Ling 2008; Gros, Gosova 2012; Seifert 2003; Ireland, Crum 2005). In 1998, organization Voluntary Inter-Industry Commerce Standards defined CPFR as a collection of new business practices that use the Internet and electronic exchange in the way to decrease the stockpile and costs radically and, at the same time, to improve the provided customer services (Skjoett-Larsen et al. 2003). Their application should contribute to significant reduction, or even elimination, of the chain (Forrester) effect (Stusek 2007). 


\section{Results and discussion}

\subsection{Characteristics of the chosen supply system}

The monitored supply system is nowadays an important multinational group of more than 250 companies. It has been built since 1993 mainly through capital acquisitions, but it also focuses on building new production capacities. The number of companies is growing continuously due to the continuously running process of restructuring within the group, whose aim is to achieve higher efficiency of the business activity. It is currently the largest group in the Czech agriculture and food industry, and the second largest chemical group in the Czech Republic (behind UNIPETROL, a.s.). That is why this group was chosen for description, assessment, and analysis of the cooperation within.

The company was, at the time it was established, solely a trading company, primarily focusing on the area of chemistry. After its establishment, it took over the activities of its parent trading company, a.s., which focused exclusively on the trade with agrochemicals on the Czech market. As the time passed, and in view of the highly competitive environment in the trade, the company invested into the distribution network and manufacturing. It gradually extended the scope of its business by pesticides, stains, and other chemicals, fuels, agricultural commodities, fodder, and foodstuffs. It was the beginning of formation of an industrial production group. Its elemental strategy is based on creation and continuous improvement of a vertically integrated group covering the entire supply chain from the primary raw materials to the end consumers in agriculture and the food industry. When it was being built, they first specified what activities are performed in agriculture on the basis of which all the inputs and outputs were defined, and the supply system was gradually created through vertical integration. This procedure fully complies with the proposed procedure of building supply system by (Gros, Grosova 2012). They propose, in the first step, separation of abstract requirements from the executors, i.e. defining all the activities that are necessary for implementation of the customer value, and assigning a particular executor to individual activities only in the second step.

The group aims to achieve the leading market position in the key business segments in the area of Central Europe. The whole supply system is formed in the way to be able to made use of the synergistic effects in the company management, in their production, but also in the area of e.g. central purchase. This results in cooperation between sup- ply subsystems, which use the land, chemistry, animal and arable farming, and the food industry. The acquisitions were, according to the sole shareholder of the group, made on the basis of rational decision making, business plans, and return on investments with respect to the highly turbulent, changeable business environment, where there are permanently significant changes with frequently inaccurate forecasts. Success of acquisitions was mainly given the confidence of banks, due to which it was possible to restructure the newly acquired companies. Today they are successful and competitive companies in the market

The parent company still mainly focuses on acquisitions of companies that fit in the concept of building an integrated agricultural and food complex in the area of Central Europe, and also on building new manufacturing capacities. Nowadays, the company operates in 18 countries of 4 continents. As for Central Europe, it is mainly in the Czech Republic, but also in Slovakia, Germany, and Hungary.

\subsection{Characteristics of the chemistry segment}

The first acquisition of a chemical company within the monitored group was made in 1996. Since then, the segment of chemistry has gradually been restructured. A detailed history of this restructuring until the end of 2013 is described in a diploma thesis (Vrbova 2015). The supply system has been built step by step with a structure where the principal chemical companies are located on a horizontal line. By the end of 2013, the group had 23 chemical companies and 1 chemical group abroad. With the exception of three companies, the parent company was their $100 \%$ owner. A vast majority of them were joint-stock companies, and in the case of the foreign companies, it was an analogue of the legal form of a joint-stock company.

They include companies dealing with production in the area of qualified chemistry, fertilizers, agrochemicals, and plastics. The emphasis is also placed on the area of research and development. These companies form the second largest chemical group in the Czech Republic and they also have a significant position on the European market. There has also been, for example, a purchase of a $100 \%$ share in the ordinary stock of a chemical company in China in 2006.

The segment of chemistry has been built step by step from the original company trading with fertilizers, which laid the foundations of the direction of the entire group. In the course of time, the company invested into the distribution network, 
acquisitions of ZZN type companies (agricultural supplies and purchase), but also ACHP (an agrochemical company) acquisitions, and subsequently into manufacturing. This gradually resulted in creation of the chemical segment (supply subsystem) within the group. The supply subsystems mostly originated on the basis of raw material, or material, successions. For example, in the area of fertilizers, the first step was creation of a distribution network. Then there was an acquisition involving a manufacturer of fertilizers, later on another two companies producing raw materials for production of fertilizers, and then some other manufacturers of fertilizers abroad. The idea of the acquisitions was to support the basic strategy of the parent company, i.e. creation of vertically integrated supply subsystems covering entire supply chains in the given area of business, i.e. the chemical industry, when Clock Speed is slow (Ling 2008).

\subsection{Cooperation within the chemistry segment}

Cooperation within the group on the basis of vertical integration and application of a model of an efficient supply system is given by the characteristics of the industry and the products manufactured in the chemical industry.

Successful operation of the given group is mainly based on long-term relationships with the partners (with some of them for more than 20 years) and utilization of synergies. If we look at the companies and segments belonging to the group, it is obvious that the efforts aim to build up an integrated agriculture-food complex, which is built with the idea of mutual cooperation across individual segments (units). To achieve this target, it is necessary to include some other segment in this complex. They are the following segment: the segment of chemistry, which produces fertilizers for agriculture and substances used in the food industry, the segment of renewable sources, which supplies the sector of agriculture with fuels and processes biomass from which it produces biofuels and electric power, the segment of ground technologies, which deals with sale, servicing, and other services in the area of farming, construction, and transport technology.

The latest segment is the segment of media, which, among other activities, ensures promotion of the products and services of the companies from all the group segments.

It is obvious that the built up group is a complex, large system, which consists of 6 relatively heterogeneous units. Therefore, its management is difficult and significantly decentralized. Individual companies in the group operate to a considerable extent as independent economic entities. They are subordinated to the decisions of their parent company, for example, in the area of investment decisions or entering into over-the-limit contracts.

Within the group, it is possible to distinguish levels of cooperation:

- cooperation between the subsidiaries and the parent company, a.s.,

- cooperation of companies within individual segments,

- cooperation across individual segments.

The subsidiaries can cooperate with the parent company either on the administrative level, where it mainly concerns issuance of directives by the parent company relating e.g. to purchase, sale, transport, legislative or whole-company measures, and other documents that are binding for the subsidiaries, or on the business level, where it is e.g. central purchase of selected items and services, particularly those which can be used regardless of the focus of activities of individual companies, i.e. office stationery, computers, software, packaging materials. On the other hand, raw materials, materials and other company-specific inputs cannot be purchased centrally. It is mainly due to the differences in qualitative parameters of the inputs from individual suppliers, the total volume of purchased inputs, or logistics costs (e.g. it is worth bringing sulphuric acid, considering the logistics costs, from places that are not farther than $400 \mathrm{~km}$ away).

Cooperation of companies within the segment of chemistry differs in individual companies and their SBUs due to the different production programmes of individual companies. Some products are company-specific, e.g. pharmacy. Also, the portfolio of the suppliers of raw materials or the customers can be very narrow. That is why the segment of chemistry also includes companies and SBUs that, within this segment and also within the entire group, do not find any suppliers or customers with whom they could cooperate. However, also these companies may draw on the fact that they belong to an important group, which has built a very good name not only in the Czech Republic, but also abroad, and is perceived as a strong, stable, and solvent corporation. Its members take advantage of this fact e.g. while negotiating contractual conditions with their customers or suppliers outside the given group.

Cooperation of companies within the segment of chemistry mainly consists in making common decisions about fundamental changes in production, about the volume of production and produc- 
tion capacities. Each company makes decisions about their production portfolio itself. The decentralized status ensures replaceability of items and better coverage of the market. The parent company approds only significant changes. The responsible managers of individual companies deal together for example with free or insufficient production capacities, plan of material flows of selected items between companie, effective railway transport. The example of collaboration within chemical companies is in the case of occurrence of an expected or unexpected situation of stoppage in production of the one item in one company. In this case the demand can be satisfied from production of another company in the concern. For example, some fertilizers, or raw materials for their production, are manufactured in two or three companies.

A positive effect of central solution to the capacities can mainly be seen in better utilization of the capacities of the companies and in lower logistics costs. For example, if one of the companies is going to be, in the following six months, short of nitric acid, another three group companies can offer their free capacities. Then, a half-year plan of material flows is created on the basis of this offer. This is also used for making transport more effective. They plan formation of a so-called complete train consisting of the own and hired railway cargo carriages and a competitive tendering to choose the carrier who will transport the given raw material between the companies.

Next cooperation within the segment of chemistry can be found in the area of sharing information. In this area, it was possible to continue in the more than 150-year-old tradition of the chemical industry in the Czech Republic, in the close cooperation among chemical companies (before the establishment of the group), where the chemical industry was designed in the way to be selfsufficient, and the companies were interlinked as for the raw materials. Some companies share, with their key customers or suppliers and almost on a daily basis, information concerning the volume of the stockpile, the volume of the expected production, and other facts in the way to synchronize the material flows through the companies within the segment of chemistry, but also outside this segment.

Another example of cooperation is rotation of managers among individual companies in the segment of chemistry. This rotation aims to achieve rationalization of manufacturing processes, distribution, and the overall improvement of cooperation between the companies on the basis of the experience and expertise acquired this way.
Cooperation of companies across individual segments of the group can be best observed, among chemical companies, in the company which mainly deals with production of fertilizers. Its suppliers are mostly companies focused on chemistry, which can be, but not necessarily are, a part of the group. Their choice depends on a number of factors, especially the type, price, and volume of the purchased input. The supply system in the area of fertilizers is relatively short, having about 5 levels. It includes manufacturers of primary raw materials, manufacturers of raw materials for production of fertilizers, manufacturers of fertilizers themselves, distributor, and end consumers. The group has representatives on almost each level. For example, one group company processes a huge amount of ammonia, which it purchases from more suppliers. The subsequent link is usually a company from the segment of agriculture, which can be both end consumers and distributors for next companies from the segment of agriculture or outside this segment. As an example of a subsequent link, it is possible to mention a company dealing with sale of industrial fertilizers not only to companies in the segment of agriculture, but also through the e-shop and distribution centres, and to the general public. Another example of cooperation is that with a company that owns a distribution network for sale of fertilizer and has specialized advisors who support the products of the manufacturer of fertilizers in their regions.

Another example of cooperation across individual segments is so-called field days, where companies from different segments of the group present their products, e.g. fertilizers, seeds, farming technology.

Cooperation of the companies across individual concern segments mainly consists in ensuring an effective material flow, but also e.g. in implementation of common promotional events.

\section{Conclusion}

In pursuit of increased competitiveness, businesses strive for mutual cooperation with the maximum possible use of synergistic effects of such cooperation. This results in creation of more and more complex and extensive supply systems. They can be, from the point of view of the systems theory, characterized as open, dynamic systems with adaptive target behaviour of the economic type, with a complex dynamic structure. These characteristics then significantly affect behaviour of the entire system, and also the ways of cooperation both within the system and with its surroundings. 
Through an analysis of the cooperation within a agricultural and food supply system focusing on the segment of chemistry that has been created for more than 20 years, the following particular advantages of cooperation has been confirmed: overall improvement of cooperation between the companies, strengthening of informal cooperation, sharing experience, the possibility of application of internal benchmarking, extension of market possibilities, improvement or achievement of the leading market position in the key segments of the business, increased efficiency of the business, increased credibility in the eyes of banks, customers, and suppliers, a better negotiation position when entering into contracts, replaceability of the production capacities, increased efficiency of material flows, their synchronization from the primary raw materials to the end consumers, increased reliability of deliveries, savings in costs both on the side of purchase and on the side of distribution and sales, application of bulk discounts, auctions, decreased logistics costs, transaction costs, marketing and advertising costs, cost of fuels and energies, lower raw material prices, lower administrative demands, rationalization of manufacturing processes, distribution, more efficient transport, easier overcoming of an economic crisis and crisis situations, and last but not least increased competitiveness.

When building a supply system and application of various forms of cooperation, it is essential to take account of a number of factors. Here are the identified most significant ones: willingness to share information, mutual confidence between the partners and with banks, corresponding technical equipment and ICT, system compatibility, but also harmonization of corporate cultures, length of manufacturing processes, features of the area of business.

What proved to be fundamental is the importance of making difference, before even starting to build a supply system, between the activities and their owners. This means to specify a clear vision and the strategy of the built supply system first, then to identify the necessary activities to fulfil them, and only then to build up the supply system itself by choosing suitable partners step by step. The success of this procedure, and also as inspiration for other companies, can be documented e.g. by the fact that the group, which has been built for more than 20 year by means of acquisitions and now consists of more than 250 companies, has not sold a single company to date.

\section{References}

Ballou, R. H. 2007. The evolution and future of logistics and supply chain management, European Business Review 19(4): 332-348. http://dx.doi.org/10.1108/09555340710760152

Branska, L.; Lostakova, H.; Pecinova, Z. 2013. Is a joint owner a guarantee of coordinated efforts of entities in the value network?, in $22^{\text {nd }}$ International Conference on Metallurgy and Materials METAL 2013, 15-17 May 2013, Brno, Czech Republic.

Estampe, D.; Lamouri, S.; Paris, J. C.; BrahimDjelloul, S. B. 2013. A framework for analysing supply chain performance evaluation models, International Journal of Production Economics 142: 247-258. http://dx.doi.org/10.1016/j.ijpe.2010.11.024

Harrison, A.; Hoek, R. 2005. Logistics management and strategy. $2^{\text {nd }}$ ed. London: FT Prentice Hall.

Christopher, M.; Peck, H. 2003. Marketing logistics. $2^{\text {nd }}$ ed. Oxford: Butterworth-Heinemann.

Christopher, M. 2005. Logistics and supply chain management: creating value-added networks. New York: FT Prentice Hall.

Fiala, P. 2009. Dynamicke dodabatelske site [Dynamic supply networks]. $1^{\text {st }}$ ed. Prague: Professional Publishing (in Czech).

Gros, I.; Gosova, S. 2012. Supply chain management. $1^{\text {st }}$ ed. Prerov: Vysoka skola logistiky (in Czech).

Gros, I.; Gosova, S. 2011. System approach in the Supply System Design, Acta Logistica Moravica 1(1): 43-50.

Ireland, R. K.; Crum, C. 2005. Supply chain collaboration: How to implement CPFR and other best collaborative practices. Boca Raton: J. Ross Publishing.

Kostalova, J.; Tetrevova, L. 2014. Project management and its tools in practice in the Czech Republic, in $10^{\text {th }}$ International Strategic Management Conference, 19-21 June 2014, Rome, Italy. http://dx.doi.org/10.1016/j.sbspro.2014.09.087

Lambert, D. M.; Cooper, M. C.; Pagh, J. D. 1998. Supply chain management: implementation issues and research opportunities, The International Journal of Logistics Management 9(2): 1-20. http://dx.doi.org/10.1108/09574099810805807

Ling, L. 2008. Supply chain management: concepts, techniques and practices enhancing value through collaboration. $1^{\text {st }}$ ed. Singapore: World Scientific Publishing.

Lostakova, H., et al. 2009. Diferencovane rizeni vztahu se zakazniky [Differentiated customer relationship management]. $1^{\text {st }}$ ed. Prague: Grada (in Czech).

Mentzer, J. T.; DeWith, W.; Keebler, J. S.; Min, S.; Nix, N. V.; Smith, C. D.; Zacharia, Z. G. 2001. Defining supply chain management, Journal of Business Logistics 22(2): 1-25.

http://dx.doi.org/10.1002/j.2158-1592.2001.tb00001.x 
Murphy, P. R.; Knemeyer, A. M. 2015. Contemporary logistics. $11^{\text {th }}$ ed. Harlow: Pearson Education Limited.

Robeson, J. F.; Copacino, W. C.; Howe, R. E. 1994. The logistics handbook. New York: Maxwell Macmillan International.

Rushton, A.; Baker, P. 2010. The handbook of logistics $\&$ distribution management. $4^{\text {th }}$ ed. London: Kogan Page.

Pernica, P. 2004. Logistika pro 21. století [Supply Chain Management]. $1^{\text {st }}$ ed. Prague: Radix (in Czech).

Seifert, D. 2003. Collaborative planning, forecasting, and replenishment - how to create a supply chain advantage. New York: AMACOM.

Stank, T. P.; Keller, S. S.; Daugherty, J. 2011. Supply chain collaboration and logistical service performance, Journal of Business Logistics 22(1): 29-48.

http://dx.doi.org/10.1002/j.2158-1592.2001.tb00158.x

Synek, M., et al. 2007. Manazerska logistika [Managerial logistics]. $4^{\text {th }}$ ed. Prague: Grada (in Czech).

Synek, M., et al. 2011. Manazerska ekonomika [Managerial economics]. $5^{\text {th }}$ ed. Prague: Grada (in Czech).

Skjoett-Larsen, T. S.; Thernoe, CH.; Andersen, CH. 2003. Supply chain collaboration: theoretical perspectives and empirical evidence, International Journal of Physical Distribution 33(6): 531-549. http://dx.doi.org/10.1108/09600030310492788

Stusek, J. 2007. Rizeni provozu v logistickych retezcich [Traffic management in supply chains]. $1^{\text {st }}$ ed. Prague: C. H. Beck (in Czech).
Tetrevova, L.; Vlckova, V. 2012. Strategic alliances in the context of strategic partnerships from the point of view of the Czech Republic, in $4^{\text {th }}$ WSEAS World Multiconference on Applied Economics, Business and Development, AEBD 2012, 1-3 July 2012, Porto.

Tetrevova, L. 2012. Triple helix model in practice in the Czech Republic, in $7^{\text {th }}$ International Scientific Conference Business and Management 2012, 10 11 May 2012, Vilnius, Lithuania, 1239-1246. http://dx.doi.org/10.3846/bm.2012.159

Vlckova, V.; Exnar, F; Machac, O. 2012. Quantitative methods for support of managerial decisionmaking in logistics, in $7^{\text {th }}$ International Scientific Conference on Business and Management, 10-11 May 2012, Vilnius, Lithuania. http://dx.doi.org/10.3846/bm.2012.130

Vlckova, V.; Patak, M. 2012. Outsourcing and its impact on demand planning, in $21^{\text {st }}$ International Conference on Metallurgy and Materials Metal 2012, 23-25 May 2012, Brno, Czech Republic.

Vrbova, H. 2015. Struktura vybraneho dodavatelskeho system v ceskem chemickem prumyslu [Choosen supply system structure in the Czech chemical industry]: Diploma thesis. University of Pardubice, Czech Republic (in Czech).

Waters, C. 2003. Logistics: an introduction to supply chain management. New York: Palgrave Macmillan. 